\title{
The Risk and Associated Factors of Female Sexual Dysfunction (FSD) in Women with Psoriasis
}

\author{
Adawiyah Ja, Moonyza AAK ${ }^{a}$, Hatta S ${ }^{b}$, Mohd Rizal AMc , Felix BBY ${ }^{d}$, Nik Ruzyanei NJ ${ }^{b}$, Marhani $M^{b}$, Srijit D , Ng \\ $\mathrm{CG}^{\mathrm{f}}$
}

${ }^{a}$ Department of Medicine, Universiti Kebangsaan Malaysia Medical Centre, 56000 Cheras, Kuala Lumpur,
Malaysia. ${ }^{b}$ Department of Psychiatry, Universiti Kebangsaan Malaysia Medical Centre, 56000 Cheras, Kuala Lumpur, Malaysia.

${ }^{c}$ Department of Community Health, Universiti Kebangsaan Malaysia Medical Centre, 56000 Cheras, Kuala Lumpur, Malaysia.

${ }^{d}$ Faculty of Medicine and Health Sciences, Universiti Tunku Abdul Rahman, 43000 Kajang, Selangor, Malaysia.

eDepartment of Anatomy, Universiti Kebangsaan Malaysia Medical Centre, 56000 Cheras, Kuala Lumpur, Malaysia.

${ }^{f}$ Department of Psychological Medicine, University Malaya Medical Centre, 50603 Kuala Lumpur, Malaysia.

\section{ABSTRACT}

Introduction: Psoriasis is a chronic, immune mediated, hyperproliferative skin disease that has substantial impact on the sexual functions. This study aimed to determine the prevalence and associated factors of female sexual dysfunction (FSD) in patients with psoriasis. Methods: A cross-sectional study involving 79 women with psoriasis attending two Dermatology Outpatient Clinics were interviewed and assessed for female sexual dysfunction and severity of psoriasis. The socio-demographic and clinical characteristics of the subjects were compared between the women with and without sexual dysfunction. The subjects were interviewed using Mini International Neuropsychiatric Interview (M.I.N.I.) to exclude any existing psychiatric illness. Sexual dysfunction was assessed using a validated questionnaire on sexual function and the severity of psoriasis was assessed using Psoriasis Area and Severity Index (PASI). Results: The prevalence of FSD in the patients with psoriasis was $20.3 \%$, with hypoactive sexual desire being the most prevalent problem (44.3\%). Sexual dysfunction was associated with older age, menopause, low body mass index, longer duration of marriage and presence of psoriasis in the genital area. Female sexual dysfunction was highly prevalent in patients with psoriasis. Conclusion: Management of psoriasis should include assessment in patients' sexual health. Genital area involvement with psoriasis should not be overlooked as it can cause significant psychosexual distress.

Keywords: Psoriasis, female, sexual dysfunction, prevalence, risk factor, Malaysia

\section{INTRODUCTION}

Psoriasis is a chronic, multi factorial, immunemediated hyperproliferative inflammatory skin disease, which is relatively common, and it has been reported to affect $4 \%$ of Malaysian population. ${ }^{1}$ The prevalence rate in the general population ranges between $0.6 \%$ and $4.8 \%{ }^{2,3}$

Corresponding author:

Professor Dr Hatta Sidi

Department of Psychiatry,

Universiti Kebangsaan Malaysia Medical Centre

Jalan Yaacob Latif, Bandar Tun razak

56000 Cheras, Kuala Lumpur, Malaysia

Tel : +603- 91456142

Fax : $+603-91737841$
Although psoriasis occurs at any age, it has a bimodal distribution of onset i.e. one peak between 20-30 years and another between 50-60 years. ${ }^{4}$ There are no differences in age and gender in terms of severity of the disease, but those in the age group of 18 to 45 years have more impact on the quality of life (QoL). ${ }^{5}$ Psoriasis may affect any part of the body and is phenotypically classified according to the morphology, with the most common ( $80 \%$ ) being plaque psoriasis. ${ }^{6,7}$

Patients with psoriasis are vulnerable to psychological problem..$^{8-10}$ Though, rarely a lifethreatening condition, psoriasis is associated with profound psychosocial impact on their QoL. There is paucity of studies on psoriasis and sexual function. A 2-year study estimated the prevalence of sexual impairment in hospitalized Italian psoriasis 
patients. ${ }^{11}$ Out of 936 patients, 35.5\% (using the Psoriasis Disability Index), $71.3 \%$ were reported to experience sexual problems because of psoriasis. There were few other studies which also demonstrated the impact of sexual function in patients with psoriasis. ${ }^{12,5}$

This subject of psoriasis and sexual dysfunction is relatively new and unexplored in dermatology especially in South-east Asia. In the present study, we aimed to determine the prevalence of sexual dysfunction and the associated factors of female sexual dysfunction in Malaysian female patients with psoriasis.

\section{MATERIALS AND METHODS}

\section{Study design}

This observational cross-sectional study involved female psoriasis patients who were sexually active in two outpatient Dermatology Clinics at a tertiary hospitals over a period of 6 months.

Admittedly, there was absence of any earlier study with similar study design and population. Goulding et $\mathrm{al}^{13}$ reported $58 \%$ of psoriasis patients had erectile dysfunction in 204 patients in an outpatient dermatology clinic. By using single proportion calculation, the sample size $94(p=0.58, \Delta=0.1)$ was calculated. Thus, the sample size after adjusting for $20 \%$ of missing data was 112 subjects.

The subjects recruited were female psoriasis patients who attended the Dermatology Outpatient clinics.

All female patients clinically diagnosed to have plaque psoriasis by a Dermatologist were invited to participate in this study. Patients were screened for their eligibility to participate in the study based on the study selection criteria. All eligible patients gave their consent for the study.

The inclusion criteria were: (i) female patients with chronic plaque psoriasis (ii) age at least 18 years old (iii) had an active sexual life, at least 1 sexual activity in the past 4 weeks and (iv) were able to read and understand the Malay or English language. The exclusion criteria were: (i) patients in 2 months post-partum period (ii) patients with known Gynaecological disorders or other severe chronic medical illnesses and chronic immobilization that could interfere with sexual function (iii) history of psychiatric illness.

A comprehensive history and physical examination were obtained. In a dedicated room for privacy, patients were asked to rate their sexual function using a validated questionnaire with full confidentiality.

\section{Assessment tools}

\section{Psoriasis Area and Severity Index (PASI)}

Psoriasis Area and Severity Index (PASI) scale is a quantitative measurement tool to measure the severity of psoriasis based on the area of involvement and plaque appearance. It was first introduced Fredericksson and Petterson ${ }^{14}$ and it is now the most common assessment tool employed in clinical research on psoriasis.

The appearance of plaque was based on 3 criteria i.e. rate of erythema $(E)$, induration $(I)$ and desquamation (D) of plaques. Severity was rated for each category on a scale of $0-4$ ( 0 for no involvement up to 4 for very severe involvement). The body was divided into 4: head and neck (h), upper extremities (a), trunk (t) and lower extremities (l). In each of these areas, a scale of 0-6 is used to grade the fraction of total surface area that is being affected by the plaques, 0 for no area involvement up to 6 for greater than $90 \%$ involvement.

The PASI score was calculated by multiplying the sum of individual severity scores for each category by the weighted area of involvement $(0.1$ for head, 0.2 for arms, 0.3 for body and 0.4 for legs), then summing the 4 resulting quantities mathematically as follows: The minimum PASI score was 0 and the maximum score was 72 . The greater the score, the more is the severity of the disease.

\section{Malay Version of Female Sexual Function Index}

The Female Sexual Function Index (FSFI) is a brief, multidimensional self-reported questionnaire consisting of 19 items, assessing sexual dysfunction in the domains of desire, arousal, lubrication, orgasm, satisfaction, and pain. ${ }^{15}$ In this present study, the Malay Version of Female Sexual Function Index (MVFSFI) was used. MVFSFI is a validated and locally accepted questionnaire for assessment of female sexual dysfunction with the sensitivity and specificity are $99 \%$ and $97 \%$, respectively. ${ }^{16}$ Total scores is 55 , and lower indicated female sexual dysfunction.

\section{Mini International Neuropsychiatric Interview}

M.I.N.I was used as a psychometric tool to diagnose any psychiatric illness among the participants of the present study. Those suspected to have psychiatric illness were excluded from the study. M.I.N.I. ${ }^{14}$

\section{Ethical consideration}

Prior to the fieldwork, ethical approval was obtained from the Medical Research and Ethics Committee (MREC) of Universiti Kebangsaan Malaysia (Code FF-226-2011). 


\section{Statistical analysis}

Analysis of the research data was performed using the Statistical Product and Services Software (SPSS version 20.0). Appropriate statistical tests were use to analyze the data. The significant factors identified from univariate analysis were included in the logistic regression multivariate analysis. All results were 2-tailed with alpha value of 0.05 .

\section{RESULTS}

A total of 223 female patients with psoriasis, who attended Dermatology Clinic within the 6month duration of this study, were screened to participate in this study. Out of this, 141 patients were excluded. The main reason for exclusion was not being sexually active for the past 4 weeks. Other reasons were having debilitating co-morbidities, language barrier or those having depressive disorders. Eighty-two patients were recruited for the study. However, 3 were not comfortable to answer the questionnaires and withdrew upon reading the MVFSFI. Seventy-nine female patients with psoriasis were finally included in data analysis.

Table 1 summarized the characteristic of female patients with psoriasis. The average age for these patients was approximately 40 years. Majority of the patients were Malays, followed by Chinese and Indian. Slightly more than half were employed; while others were housewives and retired persons. Most of the patients had secondary education and nearly one third had tertiary education. A total of 17 patients had attained menopause.

The median age of onset was about 29 years old. More than one fifth of the subjects had genital involvement, two third with hands involvement and more than half had face involvement. Majority of the patients had pruritus. All of them received topical treatment with or without systemic treatment.

The average PASI score was 8.4 with the minimum of 0.1 and the maximum of 34.5 (Median $=6.90$ ) (Table 2). Among the 79 patients who were included in this study, 16 patients $(20.3 \%)$ were observed to have female sexual dysfunction. Almost half $(44.3 \%)$ of the patients had low desire, $15.2 \%$ had poor arousal, $11.4 \%$ had lubrication and satisfaction problem; $8.9 \%$ had orgasmic disorder. Only 6 patients (7.6\%) were reported to have sexual pain disorder (Table 3).

In the univariate analysis, older age, lower level of education, longer duration of marriage, menopause and genital involvement of psoriasis were significantly associated with female sexual dysfunction. The severity of psoriasis as measured with PASI was not associated with female sexual dysfunction (Table 4). For the analysis of the associated factors for female sexual dysfunction in women with psoriasis using Logistic regression analysis, it was revealed that being menopause may be a potential risk factors $(B=2.71, S E=2.71, O R=$ 15.75, 95\% $\mathrm{Cl}=1.97-115.36)$ and having no genital involvement is a potential protective factor $(B=-$ 1.77, $\mathrm{SE}=0.84,15.75, \mathrm{OR}=0.1795 \% \mathrm{Cl}=0.03-0.89$ )

Table I: Descriptive characteristics of the study subjects $(\mathrm{N}=79)$

\begin{tabular}{|c|c|c|}
\hline Characteristic & Mean (SD) & n (\%) \\
\hline Age (years) & $40.32(10.04)$ & \\
\hline $\begin{array}{l}\text { Race } \\
\text { Malay } \\
\text { Chinese } \\
\text { Indian } \\
\text { Others }\end{array}$ & & $\begin{array}{l}58(73.4 \%) \\
10(12.7 \%) \\
6(7.6 \%) \\
5(6.3 \%)\end{array}$ \\
\hline $\begin{array}{l}\text { Education } \\
\text { Secondary and below } \\
\text { Tertiary }\end{array}$ & & $\begin{array}{l}55(69.6 \%) \\
24(30.4 \%)\end{array}$ \\
\hline $\begin{array}{l}\text { Occupation } \\
\text { Employed } \\
\text { Housewife } \\
\text { Retiree }\end{array}$ & & $\begin{array}{l}43(54.4 \%) \\
31(39.2 \%) \\
5(6.3 \%)\end{array}$ \\
\hline $\begin{array}{l}\text { Household Income } \\
\leq \mathrm{RM} 3500 \\
>\mathrm{RM} 3500\end{array}$ & & $\begin{array}{l}44(55.7 \%) \\
35(44.3 \%)\end{array}$ \\
\hline $\begin{array}{l}\text { Smoker } \\
\text { Yes } \\
\text { No }\end{array}$ & & $\begin{array}{l}4(5.1 \%) \\
75(94.9 \%)\end{array}$ \\
\hline $\begin{array}{l}\text { Menopause } \\
\text { Yes } \\
\text { No }\end{array}$ & & $\begin{array}{l}17(21.5 \%) \\
62(78.5 \%)\end{array}$ \\
\hline $\begin{array}{l}\text { Marital status } \\
\text { Married } \\
\text { Single } \\
\text { Divorcee }\end{array}$ & & $\begin{array}{l}71(89.9 \%) \\
3(3.8 \%) \\
5(6.3 \%)\end{array}$ \\
\hline $\begin{array}{l}\text { Duration of marriage } \\
\text { (years) }\end{array}$ & $14.97(10.45)$ & \\
\hline No. of children & 2.32 (1.77) & \\
\hline Partner's age (years) & $43.43(9.95)$ & \\
\hline $\mathrm{BMI}\left(\mathrm{kg} / \mathrm{m}^{2}\right)$ & $28.30(5.51)$ & \\
\hline
\end{tabular}


Table II: Clinical characteristics of psoriasis of the subjects $(\mathrm{N}=79)$

\begin{tabular}{|c|c|c|}
\hline $\begin{array}{l}\text { Clinical } \\
\text { characteristic }\end{array}$ & Mean (SD) & n (\%) \\
\hline $\begin{array}{l}\text { Age at onset of } \\
\text { psoriasis (years old) }\end{array}$ & $28.70(11.28)$ & \\
\hline $\begin{array}{l}\text { Duration of psoriasis } \\
\text { (years) }\end{array}$ & $11.74(8.62)$ & \\
\hline \multicolumn{3}{|l|}{ Genital involvement } \\
\hline Yes & & $18(22.8 \%)$ \\
\hline No & & $61(77.2 \%)$ \\
\hline \multicolumn{3}{|l|}{ High impact area } \\
\hline involvement & & $58(73.4 \%)$ \\
\hline Yes & & $21(26.6 \%)$ \\
\hline \multicolumn{3}{|l|}{ No } \\
\hline \multicolumn{3}{|l|}{ Hands involvement } \\
\hline Yes & & $51(64.6 \%)$ \\
\hline No & & $28(35.4 \%)$ \\
\hline \multicolumn{3}{|l|}{ Face involvement } \\
\hline Yes & & $43(54.4 \%)$ \\
\hline No & & $36(45.6 \%)$ \\
\hline \multicolumn{3}{|l|}{ Breasts involvement } \\
\hline Yes & & $37(46.8 \%)$ \\
\hline No & & $42(53.2 \%)$ \\
\hline \multicolumn{3}{|l|}{ Joint involvement } \\
\hline Yes & & $9(11.4 \%)$ \\
\hline No & & $70(88.6 \%)$ \\
\hline \multicolumn{3}{|l|}{ Pruritus } \\
\hline Yes & & $66(83.5 \%)$ \\
\hline No & & $13(16.5 \%)$ \\
\hline \multicolumn{3}{|l|}{ Treatment } \\
\hline Topicals only & & $43(54.4 \%)$ \\
\hline Topicals and & & $15(19.0 \%)$ \\
\hline systemic & & $13(16.5 \%)$ \\
\hline Topicals and & & $8(10.1 \%)$ \\
\hline phototherapy & & \\
\hline Topicals, systemic & & \\
\hline $\begin{array}{l}\text { and photother } \\
\text { PASI score }\end{array}$ & $8.39(7.00)$ & \\
\hline
\end{tabular}

PASI = Psoriasis Area and Severity Index

Table III: Female sexual dysfunction based on Malay Version of Female Sexual Function Index (MVFSFI) in the study subjects $(\mathrm{N}=79)$

\begin{tabular}{lcc}
\hline $\begin{array}{l}\text { FSFI } \\
\text { domains }\end{array}$ & $\begin{array}{l}\text { Score } \\
\text { Mean (SD) }\end{array}$ & $\begin{array}{l}\text { Sexual } \\
\text { dysfunction* } \\
\mathrm{n}(\%)\end{array}$ \\
\hline Desire & $5.34(1.28)$ & $35(44.3)$ \\
Arousal & $12.48(2.93)$ & $12(15.2)$ \\
Lubrication & $14.78(3.35)$ & $9(11.4)$ \\
Orgasm & $7.51(1.97)$ & $7(8.9)$ \\
Satisfaction & $15.34(3.63)$ & $9(11.4)$ \\
Pain & $11.22(2.74)$ & $6(7.6)$ \\
Overall & $66.78(12.83)$ & $16(20.3)$ \\
\hline
\end{tabular}

*Low sexual desire $=$ total scores of items 1 and 2 were $\leq 5$

Poor sexual arousal $=$ total scores of items 3, 4, 5 and 6 were $\leq 9$

Lubrication problem $=$ total scores of items 7, 8, 9 and 10 were $\leq 10$

Sexual orgasmic disorder $=$ total scores of items 11 and

12 were $\leq 4$

Low sexual satisfaction $=$ total scores of items $13,14,15$

and 16 were $\leq 11$

Sexual pain disorder $=$ total scores of items 17,18 and 19 were $\leq 7$

Overall female sexual dysfunction $=$ total scores of all items were $\leq 55$

\section{DISCUSSION}

The results of the present study showed that $20 \%$ of the patients were having FSD with almost half having low sexual desire. The associated factors of FSD were older age, menopause, low body mass index and genital involvement of psoriasis. The severity of psoriasis was not found to be a significant associated factor.

The prevalence of FSD in the present study was slightly lower than in two previous local studies in different cohorts of patients. ${ }^{17,18}$ Sidi et $\mathrm{al}^{19}$ reported a prevalence rate of $29.6 \%$ while Ishak et $\mathrm{al}^{20}$ reported $25.8 \%$. Both were in the setting of primary care clinic, where the study population were patients receiving treatment for various illnesses from these clinics. Elsewhere, the reported prevalence rate ranged between $5 \%-70 \%{ }^{20-25}$ The difference in the prevalence rate reported worldwide may be attributed to the differences in the diagnostic criteria used, study population with varied cultural as well as socioeconomic background. Meeuwis et $\mathrm{al}^{16}$ reported that half of 209 female patients with psoriasis were diagnosed with FSD. Few other studies also showed a high prevalence of FSD (35 - 71\%) in patients with psoriasis. ${ }^{11,26}$ The large variation again was due to the use of non-standardized questions in different studies.

The most commonly reported FSD in the present study was low sexual desire, which occurred in $44.3 \%$ of the study subjects. This result was similar to a previous local study. ${ }^{18}$ Sexual desire was also detected as the most prevalent domain of sexual dysfunction in many studies including in Europe and Asia. ${ }^{21,23,27,28}$ Psoriasis itself brings a negative image and stigmatization to some extent. ${ }^{29-31}$ Patients feel embarrassed, self-conscious, uncomfortable and distracted to even think about sex. These feelings may lead to lack of desire in most patients with psoriasis.

In this study, we found significantly more patients who had attained menopause and who were older in amongst the group of patients with FSD compared to non-FSD. Our results were supported by previous studies local and international studies. ${ }^{17,21,24}$ Duration of marriage was another factor found to be significantly associated with FSD in the patients with psoriasis. This was consistent with our hypothesis as well as corresponding to previous studies that longer the duration, that one is married to their partner, the greater is the likelihood of having FSD. ${ }^{17,24}$ 
Table IV: Univariate analysis of associated factors with female sexual dysfunction in women with psoriasis using ChiSquare analysis $(\mathrm{N}=79)$

\begin{tabular}{|c|c|c|c|c|c|}
\hline & $\begin{array}{l}\text { Female sexual } \\
\text { Absent } \\
\mathrm{n}(\%)\end{array}$ & $\begin{array}{c}\text { dysfunction }{ }^{\#} \\
\text { Present } \\
\mathrm{n}(\%)\end{array}$ & Chi-Square & $\begin{array}{c}p \\
\text { value }\end{array}$ & $\begin{array}{c}\mathrm{OR} \\
(95 \% \mathrm{Cl})\end{array}$ \\
\hline $\begin{array}{l}\text { Age (years) } \\
40 \text { and less } \\
\text { More than } 40\end{array}$ & $\begin{array}{l}37(88.1) \\
26(70.3)\end{array}$ & $\begin{array}{l}5(11.9) \\
11(29.7)\end{array}$ & 3.87 & 0.05 & $\begin{array}{c}3.13 \\
(0.97-10.09)\end{array}$ \\
\hline $\begin{array}{l}\text { Race } \\
\text { Malay } \\
\text { Non-Malay }\end{array}$ & $\begin{array}{l}46(79.3) \\
17(81.0)\end{array}$ & $\begin{array}{c}12(20.7) \\
4(19.0)\end{array}$ & - & $1.00^{*}$ & $\begin{array}{c}0.90 \\
(0.26-3.18)\end{array}$ \\
\hline $\begin{array}{l}\text { Education } \\
\text { Secondary and below } \\
\text { Tertiary }\end{array}$ & $\begin{array}{r}39(70.9) \\
24(100.0)\end{array}$ & $\begin{array}{c}16(29.1) \\
0(0)\end{array}$ & - & $<0.01^{*}$ & - \\
\hline $\begin{array}{l}\text { Employment } \\
\text { No } \\
\text { Yes }\end{array}$ & $\begin{array}{l}30(83.3) \\
33(76.7)\end{array}$ & $\begin{array}{c}6(16.7) \\
10(23.3)\end{array}$ & 0.53 & 0.47 & $\begin{array}{c}1.52 \\
(0.49-4.67)\end{array}$ \\
\hline $\begin{array}{l}\text { Duration of marriage } \\
15 \text { years and below } \\
\text { More than } 15 \text { years }\end{array}$ & $\begin{array}{l}36(90.0) \\
27(69.2)\end{array}$ & $\begin{array}{l}4(10.0) \\
12(30.8)\end{array}$ & 5.27 & 0.02 & $\begin{array}{c}4.00 \\
(1.16-13.78)\end{array}$ \\
\hline $\begin{array}{l}\text { Menopause } \\
\text { No } \\
\text { Yes }\end{array}$ & $\begin{array}{c}55(88.7) \\
8(47.1)\end{array}$ & $\begin{array}{l}7(11.3) \\
9(52.9)\end{array}$ & 14.33 & $<0.01$ & $\begin{array}{c}8.84 \\
(2.57-33.40)\end{array}$ \\
\hline $\begin{array}{l}\text { Body Mass Index }\left(\mathrm{kg} / \mathrm{m}^{2}\right) \\
\text { Less than } 23 \\
23 \text { and above }\end{array}$ & $\begin{array}{c}7(70.0) \\
56(81.2)\end{array}$ & $\begin{array}{c}3(30.0) \\
13(18.8)\end{array}$ & - & $0.42^{*}$ & $\begin{array}{c}0.54 \\
(0.12-2.38)\end{array}$ \\
\hline $\begin{array}{l}\text { Duration of psoriasis } \\
11 \text { years and below } \\
\text { More than } 11 \text { years }\end{array}$ & $\begin{array}{l}33(76.7) \\
30(83.3)\end{array}$ & $\begin{array}{c}10(23.3) \\
6(16.7)\end{array}$ & 0.53 & 0.47 & $\begin{array}{c}0.66 \\
(0.21-2.04)\end{array}$ \\
\hline $\begin{array}{l}\text { Genital involvement } \\
\text { Yes } \\
\text { No }\end{array}$ & $\begin{array}{l}11(61.1) \\
52(85.2)\end{array}$ & $\begin{array}{l}7(38.9) \\
9(14.8)\end{array}$ & 5.01 & 0.03 & $\begin{array}{c}0.27 \\
(0.08-0.89)\end{array}$ \\
\hline $\begin{array}{l}\text { Face involvement } \\
\text { Yes } \\
\text { No }\end{array}$ & $\begin{array}{l}33(76.7) \\
30(83.3)\end{array}$ & $\begin{array}{c}10(23.3) \\
6(16.7)\end{array}$ & 0.53 & 0.47 & $\begin{array}{c}0.66 \\
(0.21-2.04)\end{array}$ \\
\hline $\begin{array}{l}\text { Hands involvement } \\
\text { Yes } \\
\text { No }\end{array}$ & $\begin{array}{l}40(78.4) \\
23(82.1)\end{array}$ & $\begin{array}{l}11(21.6) \\
5(17.9)\end{array}$ & 0.15 & 0.70 & $\begin{array}{c}0.79 \\
(0.24-2.56)\end{array}$ \\
\hline $\begin{array}{l}\text { Breast involvement } \\
\text { Yes } \\
\text { No }\end{array}$ & $\begin{array}{l}27(73.0) \\
36(85.7)\end{array}$ & $\begin{array}{c}10(27.0) \\
6(14.3)\end{array}$ & 1.98 & 0.16 & $\begin{array}{c}0.45 \\
(0.15-1.39)\end{array}$ \\
\hline $\begin{array}{l}\text { Joint } \\
\text { Yes } \\
\text { No }\end{array}$ & $\begin{array}{c}7(77.8) \\
56(80.0)\end{array}$ & $\begin{array}{l}2(22.2) \\
14(20.0)\end{array}$ & - & $1.00^{*}$ & $\begin{array}{c}0.88 \\
(0.16-4.68)\end{array}$ \\
\hline $\begin{array}{l}\text { Pruritus } \\
\text { Yes } \\
\text { No }\end{array}$ & $\begin{array}{c}50(75.8) \\
13(100.0)\end{array}$ & $\begin{array}{c}16(24.2) \\
0(0)\end{array}$ & - & 0.06 & - \\
\hline $\begin{array}{l}\text { Treatment } \\
\text { Topical only } \\
\text { Topical plus others }\end{array}$ & $\begin{array}{l}34(79.1) \\
29(80.6)\end{array}$ & $\begin{array}{l}9(20.9) \\
7(19.4)\end{array}$ & 0.03 & 0.87 & $\begin{array}{c}0.91 \\
(0.30-2.75)\end{array}$ \\
\hline $\begin{array}{l}\text { PASI scores } \\
8 \text { and below } \\
\text { More than } 8\end{array}$ & $\begin{array}{l}34(77.3) \\
29(82.9)\end{array}$ & $\begin{array}{c}10(22.7) \\
6(17.1)\end{array}$ & 0.38 & 0.54 & $\begin{array}{c}0.70 \\
(0.23-2.17)\end{array}$ \\
\hline
\end{tabular}

* Fisher's exact test

\# Total scores of Malay Version of Female Sexual Function Index $\leq 55$

$\mathrm{OR}=$ Odds ratio, $\mathrm{Cl}=$ confident interval, $\mathrm{PASI}=$ Psoriasis Area and Severity Index 
In the present study, we found that the presence of genital involvement was statistically significant when comparing patients with and without FSD. Meeuwis et $\mathrm{al}^{16}$ also reported a decline in sexual health in female psoriasis patients with the involvement of genital lesions, in terms of sexual distress. Nevertheless, they did not find any significant differences in sexual dysfunction between patients with and without genital involvement. Sampogna et $\mathrm{al}^{11}$ studied the effect of the involvement of the genital area on sexual function and found patients with genital area involvement reporting higher numbers of sexual difficulties.

As Clinicians and Dermatologists in a busy clinic setting, the extension of psoriasis lesions on the patients especially in the private area like the genitals and breasts may be easily be missed out. From this study, we could see that quite a number of patients had psoriasis lesions in these areas. Therefore, we should be more thorough in examining patients and be able to recognize the potential additional distress that patients have especially with the involvement of skin lesions in the genitals.

There were few limitations in the present study. This study was difficult to conduct due to cultural and religious sensitivities especially in Malaysia, which is known for its conservative culture within the multiethnic population. Sexual issue is still a matter of taboo to be discussed openly in public, even to most of the healthcare professionals. The patients were uncomfortable to disclose personal matters particularly involving sexual aspects, thus refusing to give consent. This resulted in small sample size. There may be pre-selection bias as our samples were obtained by convenience sampling and we include a majority of patients who were in a stable relationship or marriage

\section{CONCLUSIONS}

There was significant risk of female sexual dysfunction in patients with psoriasis in Malaysia, especially low in sexual desire. Management of psoriasis should include physical and psychological aspect with consideration of patients' sexual health.

\section{Conflict of interest}

The authors have no conflicts of interests to declare.

\section{Acknowledgement}

The authors thank the financial support received from the university (UKM-DIP-2014-009) and Ms Najwa Baharuddin, MSc, from Universiti Kebangsaan Malaysia for formatting the manuscript.

Funding/support: This present study was funded by a research grant from the Universiti Kebangsaan Malaysia with code number of UKM-DIP-2014-009

\section{REFERENCES}

1. Raychaudhuri SP, Farber EM. The prevalence of psoriasis in the world. J Eur Acad Dermatol Venereol 2007:15:16-17.

2. Naldi L. Epidemiology of psoriasis. Curr Drug Targets Inflamm Allergy. 2004:3:121-128.

3. Gelfand JM, Weinstein R, Porter SB et al. Prevalence and treatment of psoriasis in the United Kingdom: a population-based study. Arch Dermatol 2005:141:1537-1541.

4. Farber EM, Nall ML. The natural history of psoriasis in 5,600 patients. Dermatologica 1974:148:1-18.

5. Gupta MA, Gupta AK. Age and gender differences in the impact of psoriasis on quality of life. Int J Dermatol 1995:34:700-703.

6. Griffiths CE, Barker JN. Pathogenesis and clinical features of psoriasis. Lancet 2007:370:263-271.

7. Chang CC, Gangaram HB, Hussein SH. Malaysian Psoriasis Registry-preliminary report of a pilot study using a newly revised registry form. Med J Malaysia 2008:63(Suppl C):68-71.

8. Choi J, Koo JY. Quality of life issues in psoriasis. J Am Acad Dermatol 2003:49 (2 Suppl):S57-61.

9. Finlay AY, Coles EC. The effect of severe psoriasis on the quality of life of 369 patients. Br J Dermatol 1995:132:236-144.

10. Rapp SR, Feldman SR, Exum ML, et al. Psoriasis causes as much disability as other major medical diseases. J Am Acad Dermatol 1999:41:401-407.

11. Sampogna $F$, Gisondi $P$, Tabolli, $S$, et al. Impairment of sexual life in patients with psoriasis. Dermatology 2007:214:144-150.

12. Turel Ermertcan A, Temeltas G, Deveci A, et al. Sexual dysfunction in patients with psoriasis. $J$ Dermatol 2006:33:772-778.

13. Goulding JM, Price CL, Defty CL et al. Erectile dysfunction in patients with psoriasis: increased prevalence, an unmet need, and a chance to intervene. Br J Dermatol 2011:164:103-109.

14. Fredriksson T, Pettersson U. Severe psoriasis- 
oral therapy with a new retinoid. Dermatologica 1978. 157:238-244.

15. Rosen R, Brown C, Heiman J, et al. The Female Sexual Function Index (FSFI): a

multidimensional self-report instrument for the assessment of female sexual function. J Sex Marital Ther 2000:26:191-208.

16. Meeuwis KA, de Hullu JA, van de Nieuwenhof et al. Quality of life and sexual health in patients with genital psoriasis. $\mathrm{Br} \mathrm{J}$ Dermatol. 2011:164:1247-1255.

17. Sidi $\mathrm{H}$, Abdullah N, Puteh SE, et al. The Female Sexual Function Index (FSFI): validation of the Malay version. J Sex Med 2007:4:1642-1654.

18. Sheehan DV, Lecrubier Y, Sheehan et al. The Mini-International Neuropsychiatric Interview (M.I.N.I.): the development and validation of a structured diagnostic psychiatric interview for DSM-IV and ICD-10. J Clin Psychiatry 1998:59 Suppl:22-33;quiz 34-57.

19. Sidi $\mathrm{H}$, Puteh SE, Abdullah N, et al. The prevalence of sexual dysfunction and potential risk factors that may impair sexual function in Malaysian women. J Sex Med 2007:4:311-321.

20. Ishak IH, Low WY, Othman S. Prevalence, risk factors, and predictors of female sexual dysfunction in a primary care setting: a survey finding. J Sex Med. 2010:7:3080-3087.

21. Zhang H, Yip PS. Female Sexual Dysfunction among Young and Middle-Aged Women in Hong Kong: Prevalence and Risk Factors. J Sex Med 2012:9:2911-2918.

22. Song $\mathrm{SH}$, Jeon $\mathrm{H}$, Kim SW, et al. The prevalence and risk factors of female sexual dysfunction in young korean women: an internet-based survey. J Sex Med 2008:5:1694-1701.

23. Echeverry MC, Arango A, Castro B et al. Study of the prevalence of female sexual dysfunction in sexually active women 18 to 40 years of age in Medellin, Colombia. J Sex Med 2010:7:26632669.

24. Burri A, Spector T. Recent and lifelong sexual dysfunction in a female UK population sample: prevalence and risk factors. J Sex Med 2011:8:2420-2430.

25. Hassanin IM, Helmy YA, Fathalla MM et al. Prevalence and characteristics of female sexual dysfunction in a sample of women from Upper Egypt. Int J Gynaecol Obstet 2010:108:219-223.

26. Gupta MA, Gupta AK. Psoriasis and sex: a study of moderately to severely affected patients. Int J Dermatol 1997:36:259-262.

27. Hayes RD, Bennett CM, Fairley CK et al. What can prevalence studies tell us about female sexual difficulty and dysfunction? J Sex Med 2006:3:589-595.
28. Oksuz E, Malhan S. Prevalence and risk factors for female sexual dysfunction in Turkish women. J Urol 2006:175:654-658:discussion 8.

29. Bohm D, Gissendanner S, Bangemann K, et al. Perceived relationships between severity of psoriasis symptoms, gender, stigmatization and quality of life. J Eur Acad Dermatol Venereol 2013:27: 220-226

30. Richard HL, Fortune DG, Griffiths CE, et al. The contribution of perceptions of stigmatisation to disability in patients with psoriasis. J Psychosom Res 2001:50:11-15.

31. Vardy D, Besser A, Amir M, et al. Experiences of stigmatization play a role in mediating the impact of disease severity on quality of life in psoriasis patients. Br J Dermatol 2002:147:736742. 
